\title{
THE ANALYSIS OF BOT STRATEGIES BASED ON GAME THEORY - CASE STUDY ON TAIWAN'S HIGH SPEED RAILWAY PROJECT
}

\author{
Tien-Chien Chen ${ }^{1}$, Yu-Cheng Lin ${ }^{2}$, Lung-Chuang Wang ${ }^{3}$ \\ ${ }^{1,2,3}$ Department of Civil Engineering, National Taipei University of Technology, \\ No. 1. Chung-Hsiao E. Rd., Sec. 3, Taipei, Taiwan, R.O.C. \\ E-mails: ${ }^{1} S U . Y U Z U @ m s a . h i n e t . n e t ;{ }^{2} y c l i n @ n t u t . e d u . t w$ (corresponding author); ${ }^{3}$ lcwang@ntut.edu.tw \\ Received 14 Dec. 2010; accepted 25 May 2011
}

\begin{abstract}
Uncertainty in a contract for some BOT (Build-Operate-Transfer) projects may allow an opportunistic developer to take advantage of information asymmetrical factors, long-term external changes, and agency dilemma to request renegotiation and to alter the contact after it has been awarded. Such requests often entrap the government in hold-up problems and result in improper payments to the developers and may even create general public dissatisfaction with a project. In this paper, the Game Theory model is used to analyze the Taiwan High Speed Railroad project to examine how developers implement different strategies at the various stages of a project to alter the contract's conditions in order to continually creating competitive advantage after they have been awarded the contract. This project developer is now facing serious financial difficulties. In this study, the financial information on the Taiwan High Speed Railroad operations was used as the foundation for conducting a simulation to calculate the project's value after this project began operation. The results will serve as reference to the best decision-making strategy for renegotiating costs in competition and cooperation so that a developer can select the optimum project offering the maximum reward. Also, the result will be offered to industries involved in market competition or act as an approach to establish future BOT policies on renegotiation.
\end{abstract}

Keywords: BOT, game theory, construction management, agency dilemma, opportunism.

\section{Introduction}

BOT (Build-Operate-Transfer) is a concession company provides financing, construction, operation, and maintenance of an infrastructure based on the government grant (Tiong 1995). At the end of the specified operating period, the ownership of the project is transferred to the government, and the project is subsequently managed and operated by the government (Levy 1996). Public-Private Partnership (PPP) is applied for making the long-term alliances between government and private developers for private resource and the public services (Ashuri et al. 2010). PPP is considered an important means of solving the problems of insufficient funds for constructing public projects and inefficient public projects (Yuan et al. 2010; Cheung et al. 2010). If participating developers or private investors involved in managing public enterprises are self-disciplined and effectively organized, the abuse and degradation of common resources can be successfully prevented (Ostrom 1990).

In fact, the rights and obligations of the participants in a public-private partnership project are relatively complicated. Typically, government establishes principles and criteria for bidding on a BOT project, and developers submit proposals with concrete conditions and qualifications to demonstrate their ability to accomplish the job. However, some developers may conceal some facts in their proposals. For example, developers may not completely reveal the costs and financial structure, the technical problems in running the business, and ability to assume liability. By combining costs, periods and profits, the developer often presents overly optimistic dynamic data in the bid quotations. Using this bidding strategy, the developer may be successfully awarded the contract (Ginevičius, Čirba 2003; Ho 2009; Zavadskas et al. 2004). Soon after signing the contract, the contractor due to external factors such as the economy, changes in the interest rate, and decrees, among others, seizes the opportunity to ask the government to renegotiate contractual conditions such as governmental investment, asset purchase, loan guarantee, and subsidies for deficit. Some developers may offer a higher initial bid for the project. After being awarded the contract, they renegotiate by asking for subsidies or budget amendments and consequently become the ultimate beneficiary (Athias, Nunez 2009). This is one of the reasons why major transportation infrastructures and systems often suffer over-spending (Flygbjerg, COWI 2004).

For the High Speed Rail (HR) BOT project in Taiwan, after award notification, the incomplete contract allowed Taiwan High Speed Rail Corporation (TH) to behave like an opportunist and win the bid. Later, $\mathrm{TH}$ took advantage of the agency dilemma to request changes to the contract conditions. This behavior created a situation where the contractor held the government $(G)$ as contract hostage to initiate a new negotiation. The contract negotiation results in the deeper interdependence 
between the contractor and the government and G's unnecessary but continuing assistance to $\mathrm{TH}$ (Guasch, Stphane 2009). After HR began operation, TH experienced serious financial losses. If re-negotiation were to occur, should TH continue to request subsidies or to elect to take exit mechanism with maximum award?

When a common property is poorly and improperly managed, it should be supervised by a central governmental office and efficiently managed by private sector enterprises. Hence, the user of a common property, such as a local community, will successfully manage the common property (Ostrom et al. 1993). The property right of public transportation belongs to the general public; hence, $G$ has the right and obligation to actively propose effective methods for supervising and resolving the difficulties experienced by HR on the principle of maintaining social interest and justice.

The objective of this research is to investigate why TH took advantage of information asymmetry by adopting an opportunism-based bidding strategy to win the HR-BOT project contract, and why TH took advantage of the agency dilemma to request changes to the contract conditions for gaining greater profits after being rewarded the contract. HR BOT project of Taiwan is a special case and the interacted relationship existed between $\mathrm{G}$ and $\mathrm{TH}$ for the competition and cooperation. The game theory is an alternative tool to such situation, which it can analyze the interaction among the joined players. HR is now in hot water due to financial crises, and TH expects to renegotiate with $\mathrm{G}$ to secure subsidies. The Discounted Cash Flow (DCF) method aided by the traditional viewpoint of utilizing corporate assets is used to calculate the Net Present Value (NPV) of the total future cash flow for HR to evaluate whether the project is worth further operating. The results will provide TH with information for making the optimal decision in the "bargain game". This paper consists of the following five sections: literature review on previous studies, introduction to game theory and research methods, background review and empirical study of the HR project, analyses of TH bargaining strategy, and conclusions.

\section{Reviewing the documents relevant to Taiwan high-speed rail project}

The NPV of a project is pre-evaluated as a standard for making decisions about pursuing an investment (Tiong, Alum 1997; Park et al. 2009). Currently Taiwan G also adopts the NPV method to determine whether a BOT projects is practicable. However, lacking experience in designing a contract and system, $G$ experiences continual disputes but lacks solutions. The theory of contract economics states that in a complete contract, one party may purchase the residual right of the other party in order to effectively carry out the contract (Grossman, Hart 1986). The project owner has the right to terminate the contract, the efficiency of solving the problem is somewhat limited (Hart, Moore 1990). Generally, the internal distribution value is greater than the external trading opportunity value in a trading relationship; both parties are bound by a specific relationship specified by fixed conditions.
Therefore agency dilemma and the resulting profit conflict emerge due to their respective goals. The hold-up problem fact causes a prevalence of the opportunism that draws support of dishonest measures to gain self-interests (Hill 1990; Rogerson 1992; Yaqub 2009). Hence, if the bid winner of an incomplete contract has the option of renegotiating, it may choose actions that reduce the efficiency of the whole society to increase the agency's profit (Rasmusen 2001; Rasmusen, Lyon 2004). The profits created by investment are generally seized by the opportunist. In order to solve such a problem, the cost of negotiation is reduced and opportunism is avoided if cooperation and mutual interest are taken into account in the contract with the franchise (Dahlstrom, Nygaard 1999b). In law and political economics, the so-called hold-up problem results from the re-bargaining afterward demanded by the one party. Thereby, the profits of the other party may be reduced (Klein et al. 1978; Williamson 1979). Furthermore, asset specificity causes the investor's profit to depend on the labor relationship, so the investor fears that the investment return may be vulnerable to ex post exploitation due to this contract hold-up (Schnabel, Wagner 1992; Hwang 2006). However, new negotiations may solve the problem of contract hold-up (Schweizer 2000; Hotchkiss et al. 2004). The design of an asymmetrical contract may include a third party in addition to the original two parties for improving the efficiency (Dewatripont 1988). A Systems Network Architecture compound agency agreement is effective in reducing ex post bargain cost (Dahlstrom, Nygaard 1999a). In an investment project, the owner of some investors may offer subsidization opportunity to other subcontractor participants. For example, automobile manufacturers in Japan have a habit of increasing the purchase scope for the original supplier (Makoto 2004). When the contact cannot be executed due to changes of circumstances, particularly the ex post communication for renegotiation under conditions of incomplete information, the "hold-up" problem will tend to strike a balance if it is fairly coordinated (Ellingsen, Johannesson 2004; Fares 2006). The simultaneous design of flexible conditions by weighing promises before hand, and changeable responses afterward will maintain contract efficiency (Aaken 2009).

Previous research on using the game theory as the basis for analyzing the aforementioned problems concerning BOT projects is presented below. The economic behavior of distributing resources by contractors of projects was discussed by Sacks and Harel (2006). Ho (2006) provided a theoretical model as the basis for $\mathrm{G}$ to renegotiate to be rescued from difficulties. Medda (2007) analyzed the bargaining process and the distribution of risk between the public and private sectors for transportation infrastructures. The Nanzih Wastewater Treatment Project that provides important experiences and lessons for both the public and private sectors is the first PPP application in Taiwan's wastewater treatment sector (Zheng, Tiong 2010). Extending the BOT project contract deadline as a variable parameter was a policy of concession for $\mathrm{G}$ to re-open negotiation with developers (Yang 2007; Shen et al. 2007). Aneta and Ewa (2008) analyzed 
PPP for obligation and right of each partner, and concluded that cooperation, not competition, will reduce costs and potential loss. Additionally, Game theory also has been applied the problem-solutions of the selection of construction site, customer-contractor dispute resolution, and the discrete optimization problem solution (Peldschus et al. 2010; Keršulienè et al. 2010; Zavadskas, Turskis 2008). Game theory and research methods will be presented in the following sections to assist TH policy makers in achieving the optimal decision and continually obtaining competitive superiority.

\section{Introduction to Game Theory and research methods}

\subsection{Game Theory}

Von Neumann and Morgenstern (1944) laid the foundation of modern Game Theory in 1944's Game Theory. Nash $(1950,1951)$ published "The Bargaining Theory" and "Non-cooperative Game Theory" to further carry forward game theory. Later, Schelling (1960) and Aumann (1968) studied the dynamics and redundancies of Non-cooperative Game Theory and found out under what conditions the participants could achieve long-term winwin cooperation through short-term conflict. The concept of "brinkmanship" proposed by Schelling (1960) argues that when participants confront each other, a disaster edge can be created causing both parties to slide toward the edge simultaneously so that they will either yield or compromise. Aumann (1959) officially defined the concept of "common knowledge" and applied it in Game Theory. The Folk Theorem states that participants will reach cooperation in a conflict environment through reward or penalty. Their views have practical value of wide application in addition to insightful theoretical accomplishment. At the initial stage of a game, one usually considers less the opponent's response so that the maximum strategy should be taken for selecting a relatively higher selfreward among the many rewards that have been minimized by the opponent. The participant does not consider what strategy his opponent will take, and favors only the dominant relation that will suppress all other strategies to bring him relatively higher rewards. The two strategies have aforementioned been confirmed and modeled mathematically (Rozen, Zhitomirski 2006). For example, the "Prisoner's Dilemma" in a single game points out that betrayal is a player's dominant strategy and does not consider an efficient result for the overall benefit of all participants. The game theory is the logical explanation of strategy to analyze the mutual interaction for policy makers; it is different from traditional analysis methods in that policy makers incorporate the knowledge and expectations of all other policy makers into the analysis structure. The game becomes an important foundation for analyzing personal reason and speculative behavior; if the participants involved in the negotiation can establish "credible commitment" under "common knowledge", a win-win situation can be achieved. When the negotiation compromise, intimidation, or lure for profit is applied as an important strategy, the "opponent" will quit after learning of the difficulties to become partner. This research applies game theory to the HR project for illustrating relevant problems.

\subsection{Methodology}

Game Theory applies systemic mathematical modeling for obtaining the "best response" strategy under conflict of interests. Through estimation, a policy maker may reasonably select the action that is the most successful or profitable to survive in the competition (Myerson 1991). Additionally, the time types of interaction based on game strategy includes "static game" and "dynamic game" with differences in "complete information" and "incomplete information". In a static competition, the participant (without time factor) may act without knowing the decisions made by other participants; he makes continual decisions depending on the chronological order of actions made by other participants. A tree structure is usually used to illustrate the dynamic game, which considers which strategies the participants take and how the strategies influence the outcome. The number of participants (two or more), benefits (either consistent or conflicting, or both), characteristics of information (complete or incomplete), number of game repetitions, and whether the actions involve communication, promise or threat affect the content and the degree of complexity of the game (Child, Faulkner 1998). Game Theory provides new tools for conducting research in addition to breaking through traditional thinking modes for analyzing this mutually influenced strategy. The HR case applies the following two game models and uses the Nash Equilibrium (NE) solution to explain the best response; the NE method is used to analyze the results of mutual interactions among the sets of decision policies selected by each participant. In NE, the strategy of each participant should be the best timely response to the strategy of another participant, and the participant will not deviate from an equilibrium solution. But in Bayesian NE (BNE), the participant will not change the value of estimating the probability for other participants selecting the strategy, nor will he change his own strategy. In Sub- game perfect NE (SPNE), there are many games of different time sequences, and the NE of the last game is determined and used repetitively to counter-analyze the game result until the starting point is reached.

Incomplete information static game that applies Bayes' theorem to estimate the participant's strategy probability is also called the Bayesian game. It is defined as:

$$
\Gamma_{B}=\left[I ;\left\{A_{i}\right\}_{i=1}^{I} ;\left\{T_{i}\right\}_{i=1}^{I} ; F ;\left\{u_{i}\right\}_{i=1}^{I}\right],
$$

where: $I$ is a set of all the participants; $A_{i}$ is the action set of participant $P_{i}, a_{i} \in A_{i}$ represents $P_{i}$ any action; $T_{i}$ represents the type set of private information for $P_{i} ; t_{i} \in T_{i}$ represents any type set and $t_{i}$ is known by $P_{i}$ but not other participants; $F$ represents type profile, the probability of the distribution function of $t=\left(t_{1}, t_{2}, \ldots, t_{I}\right)$ or the judgment on the type profile made by participant $P_{i}$. The reward received by $P_{i}$ is determined by the action of all 
participants and the type $t_{i}$ of $P_{i}$. Therefore, $u_{i}$ is defined as $u_{i}=\left(a_{1}, \ldots a_{I}, t_{i}\right)$. In this structure, the strategy taken by $P_{i}$ is a decision rule, which is function to reflect $T_{i}$ to $\mathrm{A}_{i}$, and illustrate what action to take if the type of $t_{i}$ is $P_{i}$.

For example, merchandise is auctioned based on the highest bidding price. If only $\mathrm{A}$ and $\mathrm{B}$ are participating in the bidding, then value $v_{A}$ and value $v_{B}$ are uniformly distributed in the range of $(0,1)$. Table 1 is the bid $b$ offered by $\mathrm{A}$ with the following possibilities: if the bidding price offered by A is higher, the probability for A to win the auction is $P_{r}=1$ with reward of $u_{A}=v_{A}-b$. If A and $\mathrm{B}$ offer the same bidding price, the probability for $\mathrm{A}$ to get the merchandise is $P_{r}=1 / 2$ with reward of $u_{A}=\left(v_{A}-b\right) / 2$. If $\mathrm{A}$ offers a lower bidding price, $\mathrm{A}$ has zero probability to gain the merchandise with reward of $u_{A}=0$. Similarly, the bid $\mathrm{b}$ offered by $\mathrm{B}$ has the same results. The only symmetric BNE in the game is $b_{A}\left(v_{A}\right)=v_{A} / 2$, and $b_{B}\left(v_{B}\right)=v_{B} / 2\left(b_{A}\right.$ : bid $b$ offered by A, $b_{B}$ : bid $b$ offered by B).

Consisting of multiple games with chronological orders, the complete information dynamic game is also called the Extensive Game; it is defined as:

$$
\Gamma_{E}=[I ; X ; P ; A ; H ; u],
$$

where: $I$ is the set of all the participants; $X=\left\{x_{1}, x_{2}, \ldots, x_{n}\right\}$ is the set of finite number of nodes; $P: X \rightarrow X \cup$ is the predecessor relationship, or empty set; $P(x)$ plots the immediate predecessor of $x$ point corresponding to every $x \in X ; A=\left\{A_{1}, A_{2}, \ldots, A_{I}\right\}$ is the set of action, and $\mathrm{A}_{i}$ represents the action that the participant $P_{i}$ may select of the set. The information rule or $H=\left\{h_{1}, h_{2}, \ldots, h_{k}\right\}$ represents how to divide all policy nodes into $k$ sets of information to illustrate the various information statuses for participants. Here information set is a singleton set that contains only one element. The game that satisfies this condition is called the perfect information game because a participant knows his own policy node; and $u=\left(u_{1}, u_{2}, \ldots, u_{I}\right)$ is the reward function with $u_{i}$ denoting the reward received by participant $P i$ at the end of each game.

Fig. 1 shows the game between the two human sexes with complete information. All nodes in the game shown in Fig. 1 are plotted as "•", and individually named as $x, x_{2}, \ldots, x_{7}$, etc. shown on the right of each node. P1 will first select B (going to basketball game) or M (going to movie). When receiving the information on the selection of B made by P1, P2 may select B (with reward of $u=20,10$ ), or $M$ (with reward of $u=0,0$ ) to response. P2 may also select $B$ (with reward of $u=0,0$ ) or $M$ (with

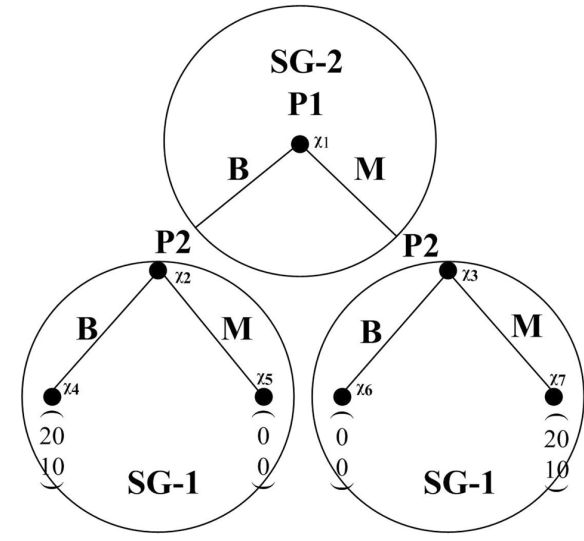

Fig. 1. Diagram showing the dynamic game between the two human genders with complete information

reward of $u=10,20)$ to response. If $\Gamma_{S G}$ denotes any subgame of $\Gamma_{E}$, the procedures of finding Sub-game perfect NE (SPNE) are as follows: (1) Finding the last sub-game, $\Gamma_{S G-1}$, and find its NE; (2) working backward to find the next upper layer sub-game, $\Gamma_{S G-2}$, and its NE. When finding $\Gamma_{S G-2}$, the portion of $\Gamma_{S G-1}$ is replaced by NE. If $\Gamma_{S G-1}$ has multiple NEs, each NE must be placed in $\Gamma_{S G-2}$ to find its solution; (3) repeating the procedures until the uppermost layer or the starting point is reached. Using the above procedure, $\operatorname{SPNE}=\{(20,10) ;(10,20)\}$ can be obtained.

Game Theory based on a NE solution is used to evaluate and confirm the following HR case.

\section{Background information of the HR case and verification}

In 1993, Taiwan's government (G) decided to solicit private sector partners for a proposed BOT project for constructing a high speed railroad; the project was open to developers in 1996. Two companies, China High Speed Rail Corporation (CH) and Taiwan High Speed Rail Corporation (TH), participated in the bidding process in 1997. In the same year, TH was rewarded the priority right to negotiate with a total construction bid expenditure of $\$ 14$ billion; TH claimed that the company could afford all expenditures and did not need financial assistance from G. Because of TH's optimism, the general public thought that $\mathrm{G}$ offered zero investment to have a HR constructed. Soon after the contract was signed, the Asian financial crisis caused changes to Taiwan's financial situation; all financing banks determined that the risks of becoming involved with the HR project were too high. At the request of $\mathrm{TH}, \mathrm{G}$ became involved in the

Table 1. Bidding results for static game (Bayesian game) with incomplete information

\begin{tabular}{l|c|c}
\hline \multicolumn{1}{c|}{ Results } & Probability $\left(P_{r}\right)$ & Reward for A $^{u_{A}}$ \\
\hline A offers higher bid and wins the merchandise & $P_{r}\left[b>\left(v_{B} / 2\right)\right]$ & $v_{A}-b$ \\
\hline A and B offer the same bid & $P_{r}\left[b=\left(v_{B} / 2\right)\right]$ & $\left(v_{A}-b\right) / 2$ \\
\hline A offers lower bid, and B wins the merchandise & $P_{r}\left[b<\left(v_{B} / 2\right)\right]$ & 0 \\
\hline
\end{tabular}


discussions between TH and banks, and in 2000, the three parties officially signed a contract. The contract specifies that the loans be approved only when $\mathrm{G}$ provides guaranty and that if $\mathrm{TH}$ terminates the contract prematurely, G may purchase all $\mathrm{TH}$ assets and first compensate the financing banks with the excess be paid to TH. The financing banks obtained a loan guarantee from $\mathrm{G}$ to safeguard the value of investment. The contract also specifies that if $G$ revokes the construct permit or management license of $\mathrm{TH}, \mathrm{G}$ must purchase the hardware currently under construction or in operation. TH received the purchase asset guarantee from G; if the market deteriorates, TH may consider whether to terminate its investment or implement the abandon option provided in the contract. During the HR construction process, G started with offering zero investment but ended up offering loan guarantee.

Furthermore, G offered TH an initial investment of more than $\$ 13$ billion. The final outcome of the project made the general public feel that there was a great difference between the original promises and final results. Additionally, the free guarantee on the huge loan was not fair to $\mathrm{CH}$ because superficially $\mathrm{TH}$ did not have to undertake any risk.

TH's unlimited demands caused the general public to doubt that $G$ was against the spirit of PPP, and to question whether the corruption of $\mathrm{G}$ offered TH unreasonable guarantee and subsidies so that $\mathrm{G}$ was critically censured from all sectors involved. In this paper, the development of the BOT project from planning, bid award, re-negotiation, construction completion, project management, and future development is studied and verified in three periods as follows.

First Period (1990-1997). From the establishment of HR engineering preparatory office by Taiwan $G$ up to the participation of $\mathrm{CH}$ and $\mathrm{TH}$ in the HR bidding; and the award to TH for its "G zero investment" strategy.

Second Period (1997-2007). After the selection of $\mathrm{TH}$ as the best applicant, all financing banks regarded the loan as too risky. TH could not obtain the loan, and requested $\mathrm{G}$ to guarantee the loan to resolve the impasse. Thus, $\mathrm{G}$ agreed to sign a three-party contract with TH and bank representatives to warrant the guaranteed purchase so that HR was constructed and opened to business.

The Last Period (2007-future). After HR began operated, TH gradually increased the number of trains running the same route and made flexible strategies such as discount tickets. By 2008, the HR loss amounted to $\$$ 2.1 billion, which was almost $65 \%$ of the HR capital, and exceeded the financial capability of HR. Thus, G should initiate the negotiation to seek solutions based on this research.

\subsection{First period}

If the parties involved in the bidding have equal strength but do not know the sealed-bid offered by the other opponent and must offer a simultaneous bid to determine the bid-winning party, this is a static game with incomplete information. Table 2 lists the results of bidding by TH and CH based on different strategies, where "h" indicates high bid; " $r$ " indicates reasonable bid; " $\mathrm{H}$ " indicates high bidding reward; "P" indicates reasonable bidding reward; "C" indicates bidding cost; " $\mathrm{C}$ " indicates reduced reward for high bidding; $I=\{\mathrm{TH}, \mathrm{CH}\}$ is the set of participants. Because all participants in the bidding process offered a bid, the set of action becomes $A_{i}=\{$ TH bidding, CH bidding \}. In other words, $A_{i}$ represents that both $\mathrm{TH}$ and $\mathrm{CH}$ offered a bid. Further, the huge amount of money involved in this project caused all participants to strive to ascertain the project's reserve price of $\mathrm{G}$ and keep their own bids secret; thus, the set of information for the participant is $T_{i}=\{\mathrm{TH}$ and $\mathrm{CH}$ knowing the reserve price of $\mathrm{G}$, but not knowing the sealed-bid price of the other's\}. Suppose both sides knew that the reserve price of $\mathrm{G}$ was tenable, then the participants sealed-bids price as same as the $P_{r}=0.5$ probability respectively. If one participant throws the sealed-bid price of $\mathrm{h}$, the other throws the sealed-bid price of $\mathrm{r}$, then $P r h=1, \operatorname{Prr}=0$. The situation of low price bidding will not occur. We do not take it into consideration because both parties strive to win the project. The set of probability distribution functions is $F_{i}=$ $\{\mathrm{TH}$ and $\mathrm{CH}$ knowing the reserve price of $\mathrm{G}$ and offering "h", winning probability being $P_{r}(0.5,0.5)$; $\mathrm{TH}$ and $\mathrm{CH}$ knowing the reserve price of $\mathrm{G}$ and offering " $\mathrm{r}$ ", winning probability being $P_{r}(0.5,0.5)$; $\mathrm{TH}$ and $\mathrm{CH}$ knowing the reserve price of G, TH offering " $h$ " and $\mathrm{CH}$ offering " $\mathrm{r}$ ", winning probability being $P_{r}(1,0)$; TH and $\mathrm{CH}$ knowing the reserve price of $\mathrm{G}, \mathrm{TH}$ offering " $\mathrm{r}$ " and $\mathrm{CH}$ offering "h", winning probability being $\left.P_{r}(0,1)\right\}$. The reward is decided by all participants' actions, information type and winning probabilities. All participants have similar actions, information type and winning probabilities with only difference in the winning probability. If both $\mathrm{TH}$ and $\mathrm{CH}$ know the reserve price of $\mathrm{G}$ and offer "h", the set of rewards is $(0.5 \mathrm{H}-0.5 \mathrm{C}-0.5 \mathrm{~L}, 0.5 \mathrm{H}-0.5 \mathrm{C}-0.5 \mathrm{~L})$; if both $\mathrm{TH}$ and $\mathrm{CH}$ offer " $\mathrm{r}$ ", the set of rewards is $(0.5 \mathrm{P}-0.5 \mathrm{C}, 0.5 \mathrm{P}-$ $0.5 \mathrm{C})$. On the analogy of this, $u_{i}=\{(0.5 \mathrm{~h}-0.5 \mathrm{C}-0.5 \mathrm{~L}$, $0.5 \mathrm{~h}-0.5 \mathrm{C}-0.5 \mathrm{~L}),(\mathrm{H}-\mathrm{C}-\mathrm{L},-\mathrm{C}),(-\mathrm{C}, \mathrm{H}-\mathrm{C}-\mathrm{L}),(0.5 \mathrm{P}-0.5 \mathrm{C}$, $0.5 \mathrm{P}-0.5 \mathrm{C})\}$. A symmetric game of $B N E$ Solution is equal to $\{(0.5 \mathrm{H}-0.5 \mathrm{C}-0.5 \mathrm{~L}, 0.5 \mathrm{H}-0.5 \mathrm{C}-0.5 \mathrm{~L}),(0.5 \mathrm{P}-0.5 \mathrm{C}, 0.5 \mathrm{P}-$ $0.5 \mathrm{C})\}$. That is because both $\mathrm{TH}$ and $\mathrm{CH}$ know the reserve price of $\mathrm{G}$ and offer a high bid with a set of rewards is $(0.5 \mathrm{H}-0.5 \mathrm{C}-0.5 \mathrm{~L}, 0.5 \mathrm{H}-0.5 \mathrm{C}-0.5 \mathrm{~L})$. Also $\mathrm{TH}$ and $\mathrm{CH}$ know the reserve pric e of $\mathrm{G}$ and offer a reasonable bid

Table 2. Results of bidding by participants with equal actions and information types, where winning probabilities are different

\begin{tabular}{l|l|l|l}
\hline \multirow{2}{*}{$\mathbf{*}$} & \multicolumn{3}{|c}{ TH } \\
\hline \multirow{3}{*}{$\mathbf{C H}$} & $\mathbf{h}$ & $\mathbf{h}$ & $\mathbf{r}$ \\
\cline { 2 - 5 } & $\mathbf{r}$ & {$[0.5 \mathrm{H}-0.5 \mathrm{C}-0.5 \mathrm{~L}, 0.5 \mathrm{H}-0.5 \mathrm{C}-0.5 \mathrm{~L}]$} & {$[-\mathrm{C}, \mathrm{H}-\mathrm{C}-\mathrm{L}]$} \\
\hline
\end{tabular}


with a set of rewards is $(0.5 \mathrm{P}-0.5 \mathrm{C}, 0.5 \mathrm{P}-0.5 \mathrm{C})$. In a single Prisoner's Dilemma game, betrayal is the Winning Strategy of the participant, and non-cooperation is the only best choice. Thus, TH bid at a higher price and was selected as the top winner with $u t h=(\mathrm{H}-\mathrm{C}-\mathrm{L})$, and the second winner with $u c h=(-C)$. Under the speculative action and limited reasonable acknowledgment, although TH won the bidding with a high price, the long contract period of 35 years will likely present many changes to numerous factors. Whether these changes are positive or negative toward the end of the contract period cannot be perceived at the present. Obviously, the opportunistic developer concealed the true situation in the bidding proposal and presented over-optimistic "G zero investment" information in the quoted prices. The bidding strategy is the key to defeating an opponent and winning the contract. The BOT project developers are the major contractors and suppliers. With the superiority of self-agency, the developers are not concerned about over expenditures at all during construction as long as the project is financed (including loans), which helps the contractor (TH itself) gain high profits. Whether the project will be profitable during future operational period is no longer the concern.

\subsection{Second period}

This stage of negotiation can be divided into two dynamic sub-games of renegotiation and changes to contract conditions with complete information. As shown in Fig. 2, $I=\{\mathrm{TH}, \mathrm{G}\}$ represents the set of participants, and $A=\{\mathrm{TH}$ requesting renegotiation, $\mathrm{TH}$ abandoning all project; $\mathrm{G}$ agreeing to the request, $\mathrm{G}$ not agreeing to the request $\}$ represents the set of actions. The set of different rules and information for the participants is $H=\{\mathrm{G}$ agreeing to renegotiation and requesting $\mathrm{TH}$ to increase the investment, or $\mathrm{G}$ not agreeing to renegotiate and removing TH's right of priority negotiation; $\mathrm{TH}$ agreeing to increase the investment or not agreeing to increase the investment and requesting $\mathrm{G}$ to purchase the assets and be loan guarantor; $G$ agreeing to purchase the assets and be loan guarantor, or $\mathrm{G}$ not agreeing to purchase the assets and to be the loan guarantor, and then TH's right of priority negotiation would be removed\}. Because TH adopted a strategy of G's refusal to negotiate and abandoned the project, TH would lose the bid cost $(\mathrm{C}), \mathrm{G}$ could agree or refuse to negotiate and request $\mathrm{TH}$ to execute the contract. Otherwise, $\mathrm{G}$ would remove TH's right of priority negotiation. If $G$ had refused renegotiation, $G$ would have had to seek the next bidder for negotiating contract or solicit a new bidder, thereby losing time and the cost for preparing the bidding (S). If $\mathrm{G}$ agreed to renegotiation and purchase the assets and be the loan guarantor, $\mathrm{G}$ would pay the subsidy (g).The set of reward functions for the participants is $u=\{\mathrm{TH}$ actively abandoning the right to priority negotiation or forced to abandon the right to priority negotiation. The reward to both parties is $u(-\mathrm{C},-\mathrm{S})$. G agreed to purchase the assets and be the loan guarantor with rewards to both parties is $u(+\mathrm{g},-\mathrm{g})\}$. At this moment, $\mathrm{G}$ has been caught in a hold-up problem. $\mathrm{G}$ would like to proceed with the project with the concern that new negotiations may lose the capital already invested. Finally, G decided to accept the renegotiation and agreed to purchase the assets and be the loan guarantor. What's more, G didn't invest money in this project. Although SPNE Solution $=\{(-\mathrm{C},-\mathrm{S}),(-\mathrm{C},-\mathrm{S})\}$, G still agreed to purchase the assets and be the loan guarantor. Therefore, the reward received by $\mathrm{TH}$ and $\mathrm{G}$ is $u=(+\mathrm{g},-\mathrm{g})$, respectively. Hence, TH solved the serious financing problem (Rasmusen 2001; Rasmusen, Lyon 2004). Because the agreement lacks a reason for G's agreeing to purchase the assets and be the loan guarantor, and it is not fair to $\mathrm{CH}$. Also, it drew pointed criticism from the general public and exposed the incapability of $\mathrm{G}$, leading to political crises.

\subsection{The last period}

The number of passengers was originally predicted by TH to be approximately 202,500 per day. However, the financial report of $\mathrm{TH}$ in 2008 presented the number of passengers was only 85,000 per day, $63.2 \%$ lower than the original pre-operation estimate. The income for the same year was $\$ 0.7$ billion, which is $72.2 \%$ lower than the original estimate of $\$ 2.6$ billion. The expenses for interest payments, operational costs, fees, and depreciation, among many others, have become a huge financial burden. From 2007 to 2008, HR had lost $\$ 2.1$ billion; its finances were facing cash flow problems and the TH is facing bankruptcy. What is the future competition dominant strategy for TH? The current solution is to use DCF to calculate the NPV of the HR project in order to evaluate whether the project is worthy of the value for continuing operations. The project is facing finance-related potential risks such as business income, management expenditures, paying debts and interest, equipment depreciation, and cash flow, among many others. Because HR has been completed and is currently in operation, its major source of income is from selling tickets. HR usage by passengers is another important factor in addition to setting the ticket price. The volume of transportation is of great importance in affecting the NPV; a higher volume of transportation raises the positive value of the project and vice versa. Hence, after converting the three factors of ticket price, number of passengers, and operational cost, which are closely related to operational income and expenditures, into risk indices, since its operation in 2007 the HR financial information has been used as the simulation data.

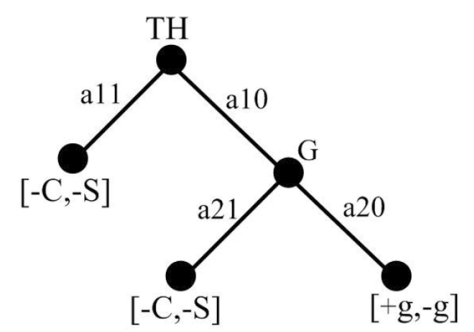

Fig. 2. Results of sub-game of renegotiation 
The results show that the project's NPV is $\$-21.6$ billion dollars as shown in Table 3 that reaches the profound outthe-money indicating that the project is not worthy of further operation. Because the operation is the beginning to recover its huge initial investment, the operation must be exposed to uncertain long-term market risks. At this time, TH is trapped in an over-optimistic "self agency dilemma". The BOT project asset is special because it is considered a "public asset," so that TH should actively negotiate for solving the problem under the principle of social justice when $G$ is aware of the tough situation. Because TH finances are open, TH's problem is known to the public, and $\mathrm{G}$ must be involved in solving the problem. Hence, both parties have similar actions and information; this period belongs to a dynamic game with complete information, which contains renegotiations and providing subsidies. The latter offers two optionsadministering purchase assets and take over HR or further providing subsidies through repeated sub-games, as shown by the set of participants of $I=\{\mathrm{G}, \mathrm{TH}\}$ in Fig. 3 . $G$ has two options for solving the problem. It could pursue a direct purchase and take over HR, which may bring about fierce resistance from $\mathrm{TH}$ or even a bankruptcy claim by $\mathrm{TH}$ to legally apply for reconstruction, even causing HR to stop working. The result does not correspond to the benefit of the general public. Another choice is to request renegotiation; TH certainly agrees on renegotiation with the hope of gaining financial assistance from G. However, both parties have different expectations. For example, $\mathrm{TH}$ expects $\mathrm{G}$ to provide subsidies for continuing operations, but $\mathrm{G}$ dares not to promise any subsidy lest it will assume further political risks. $G$ is still backed by strong public opinion polls and may take an intransigent attitude towards renegotiation. And it will request $\mathrm{TH}$ to increase investment for solving finance dilemma. Hence, the set of actions taken by participants is $A=\{\mathrm{G}$ requesting renegotiation, or purchasing and taking over HR; TH agreeing renegotiation and requesting subsidies from $G ; G$ agreeing to subsidize or not agreeing to subsidize and TH claiming bankruptcy $\}$. The set of different rules and information for the participants is $H=\{\mathrm{G}$ requesting renegotiation for increasing investment from TH or G purchasing and taking over HR; TH agreeing to increase investment or TH not agreeing to increase investment but requesting $G$ to subsidize; $G$ agreeing to subsidize or $\mathrm{G}$ not agreeing to subsidize and $\mathrm{TH}$ claiming bankruptcy to apply for reconstruction at court; $\mathrm{TH}$ succeeding in reconstruction or TH failing reconstruction and $\mathrm{G}$ purchasing and taking over directly HR\}.

In the HR project contract, the terminating clause stipulates that when G "guarantees" the purchase of TH assets, the price must be appraised by a professional appraisal agency, which usually takes the difference between the total investment (I), which does not include the land levied by $\mathrm{G}$, and the asset depreciation (dt) as the evaluated residual asset value (St) within time t. The price (At) paid by $\mathrm{G}$ for purchasing the asset must be preferentially paid to the loan banks as payment for the debt (Dt); the remaining (Ats) is then reimbursed to the $\mathrm{TH}$ investors. The total investment (I) includes the company capital stocks
(C)(reserved capital) and capital loaned from banks(D). If $\mathrm{G}$ agrees to subsidize $\mathrm{TH}$ for the insufficient reward, $\mathrm{G}$ will pay the price for allowance $(\mathrm{gU})$. Hence, the set of reward functions for participants is $u=\{\mathrm{G}$ directly purchasing and taking over HR with rewards to $\mathrm{G}$ and TH is (HR, Ats). TH agreeing to renegotiation and then increasing investment with rewards to $\mathrm{G}$ and $\mathrm{TH}$ is $(0, \mathrm{HR})$; $\mathrm{TH}$ agreeing to renegotiation and $G$ subsidizing with rewards to $\mathrm{G}$ and $\mathrm{TH}$ is $(-\mathrm{gU},+\mathrm{gU}) ; \mathrm{G}$ not agreeing to subsidize and $\mathrm{TH}$ declaring bankruptcy and successfully applying in court for reconstruction with rewards to $\mathrm{G}$ and $\mathrm{TH}$ is $(0$, HR); TH declaring bankruptcy and having its application for reconstruction denied, $\mathrm{G}$ directly purchasing and taking over HR with rewards to G and TH is (HR, Ats) $\}$. SPNE Solution $=\{(\mathrm{HR}$, Ats $),(\mathrm{HR}, \mathrm{Ats})\}$ represents the operations that are recursively repeated backward until the beginning point of the game is reached. According to contract signed by both parties, when special situations occur, G may directly purchase and compulsorily take over the HR asset. If $G$ opts to exercise this right, the rewards will then be (HR, Ats); if G requests TH to renegotiate, the subgames will be "renegotiation"or "refusal"; if TH agrees to increase the investment, the rewards will be $(0, \mathrm{HR})$. If $\mathrm{G}$ agrees to subsidize, the rewards will then be $(-\mathrm{gU},+\mathrm{gU})$. Alternatively, if TH declares bankruptcy and successfully applies in court for reconstruction, the rewards are $(0, \mathrm{HR})$. If TH declares bankruptcy but fails to apply for reconstruction so that $G$ directly purchases and takes over the HR asset, the rewards are (HR, Ats). Because the internal and external factors have great variations and risks for $\mathrm{TH}, \mathrm{TH}$ will not select "increasing the investment" or "declaring bankruptcy". While backed by public opinion, G is trying to maintain social justice and avoid a political crisis, so G will not select "agreeing to subsidize interest" or "guaranteeing income". Both parties know very well the point of "disaster edge"; they finally cooperate to take what each party needs. That is, TH gives up project management of $\mathrm{HR}$, and $\mathrm{G}$ directly purchases and takes over TH's assets, leading to rewards of (HR) to G and (Ats) to TH. The future delivery of Ats for HR is expressed by the NPV listed in row 25 (see Table 3 ) and the residual capital reservation (Ct) listed in row 20 (see Table 3). Because HR suffered a huge loss during the operation, profit-seeking enterprise income tax and rate were not taken into account.

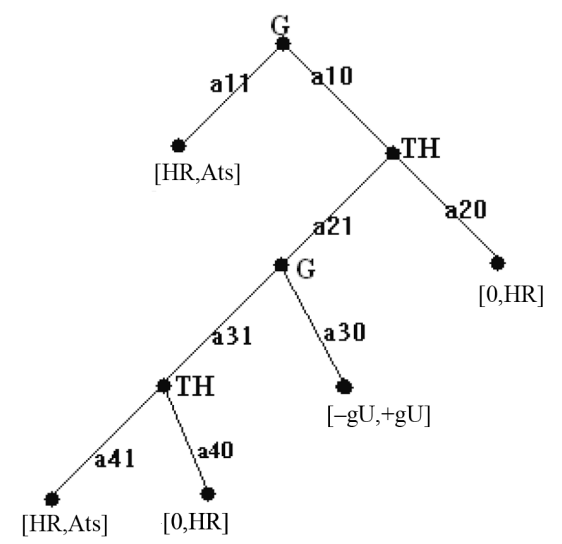

Fig. 3. Results of renegotiation that consists of multiple sub-games 


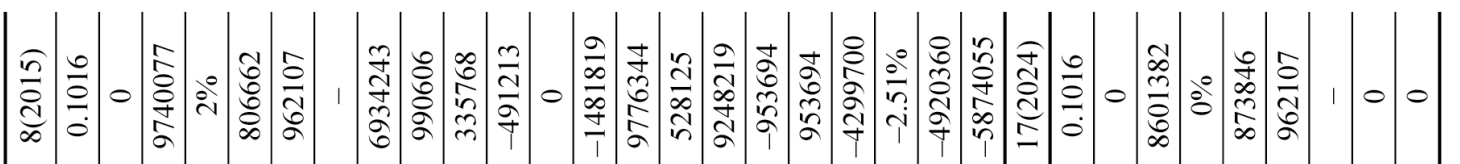

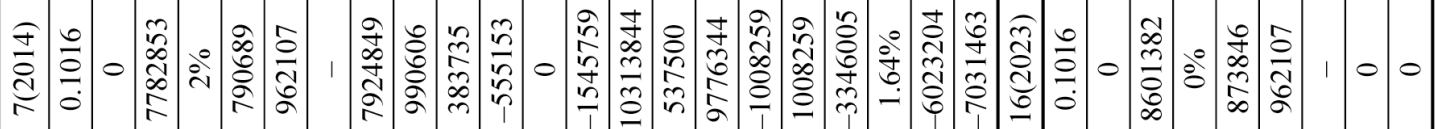

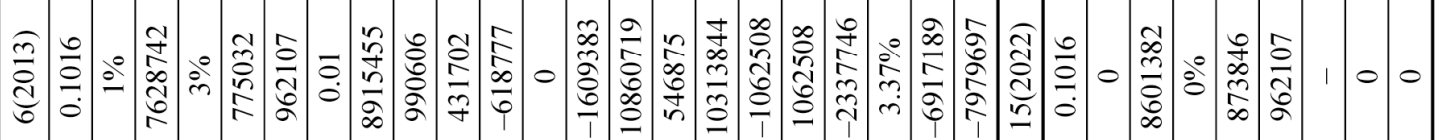

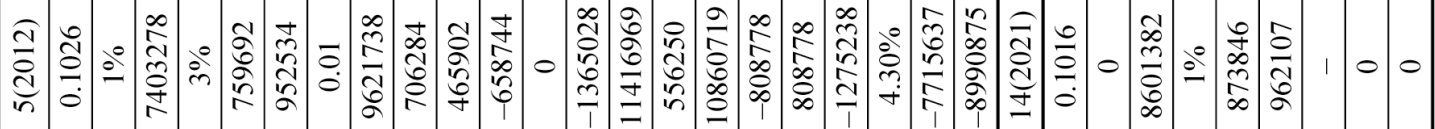

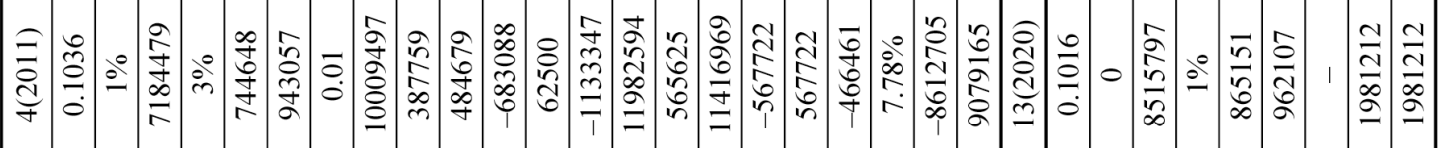

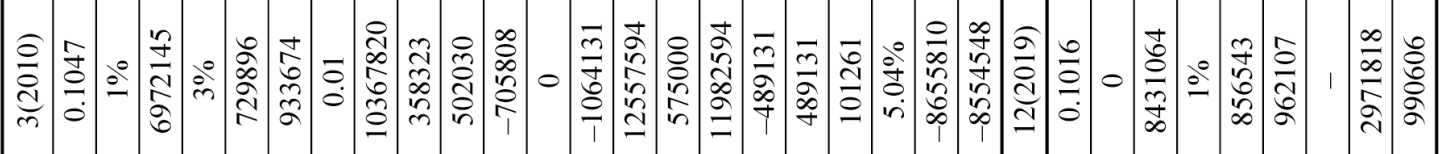

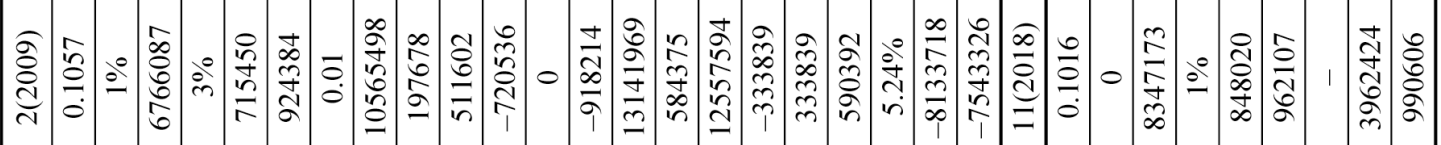

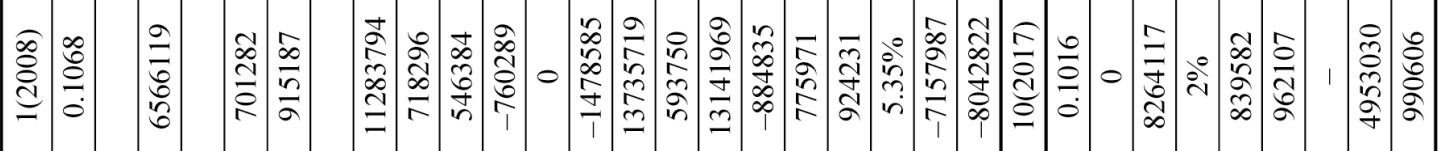

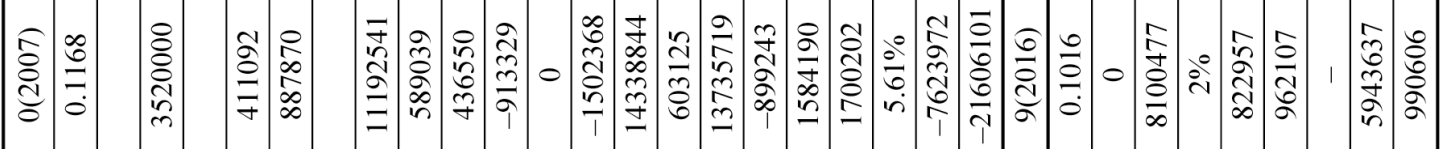

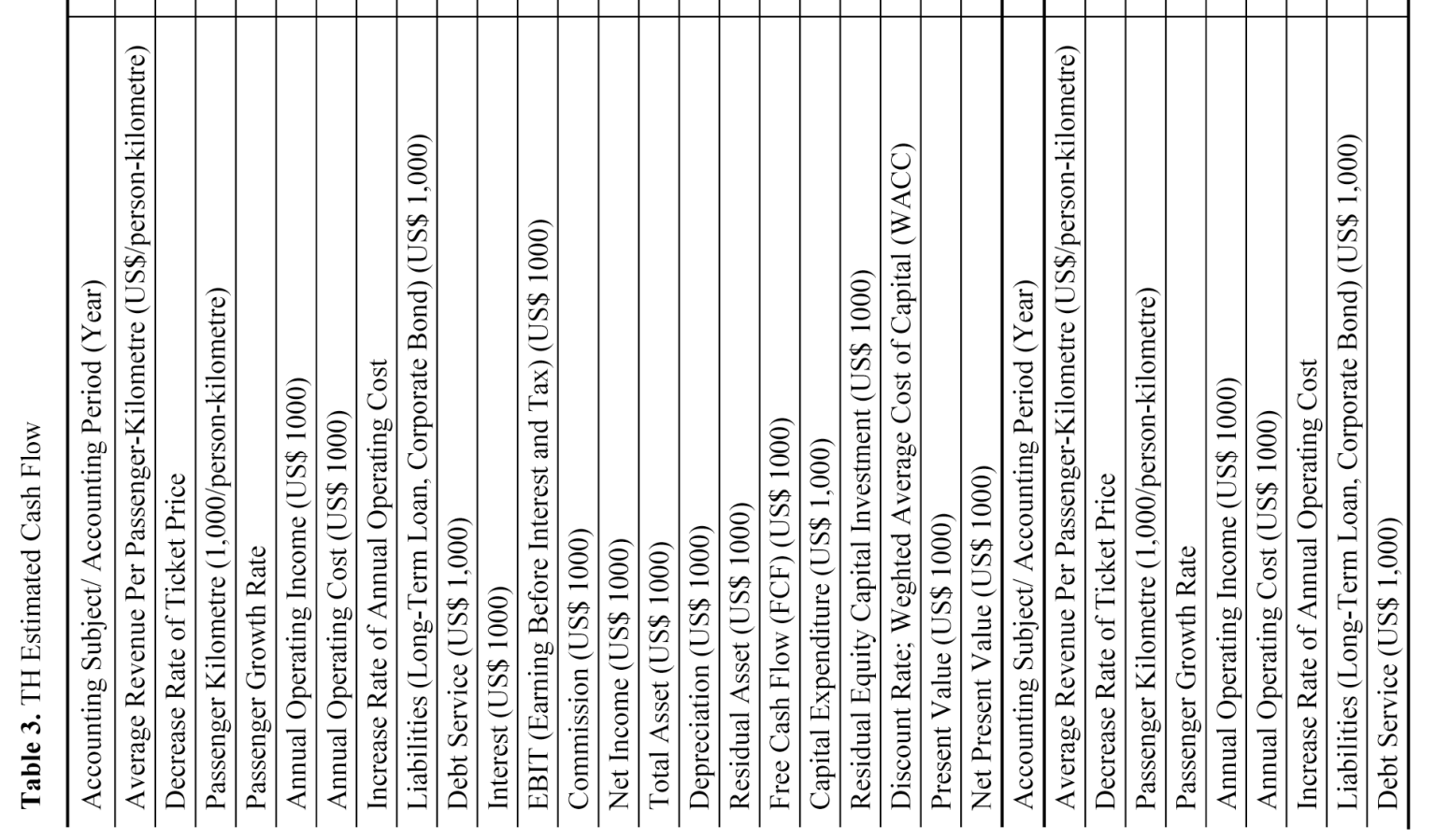




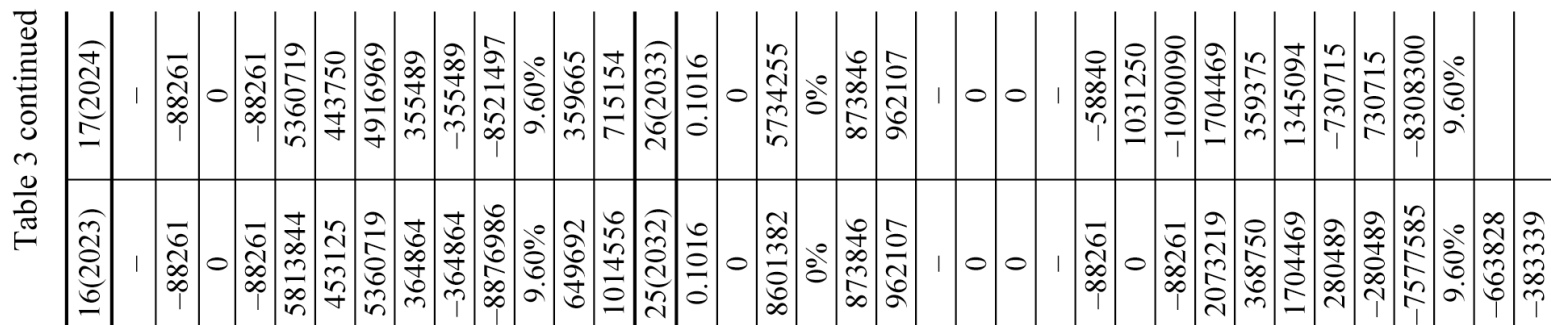

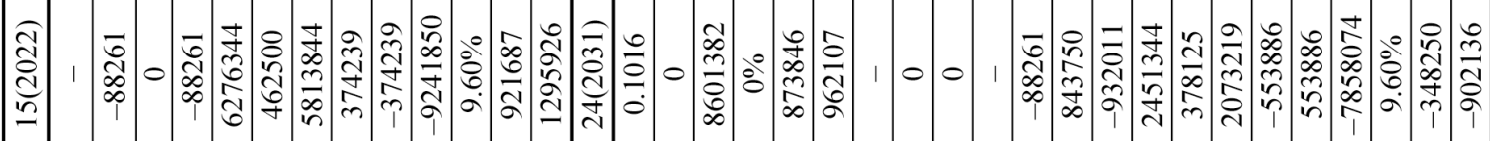

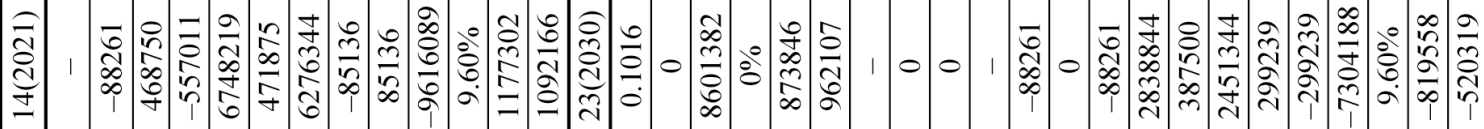

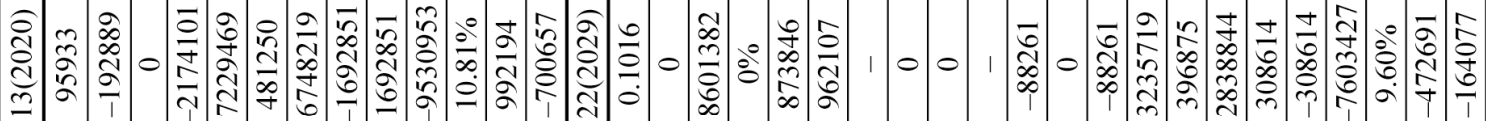

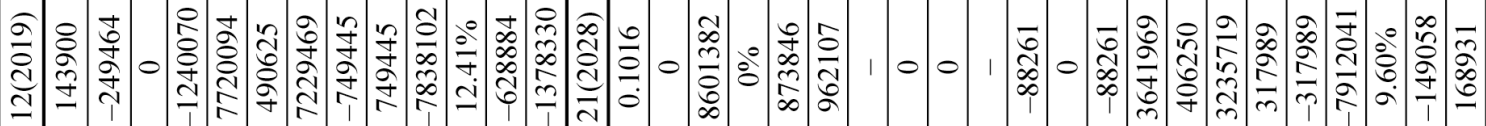

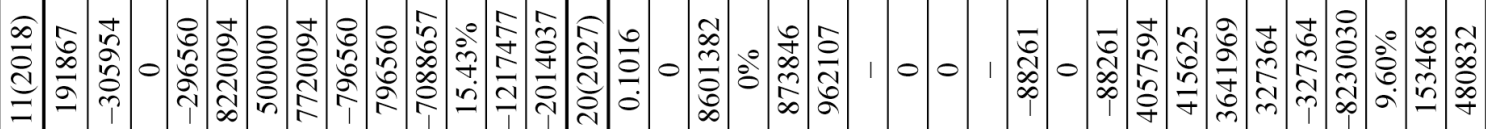

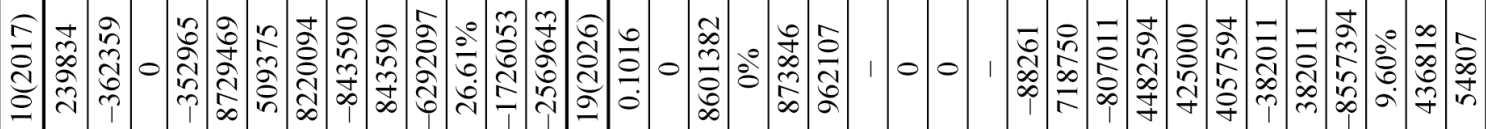

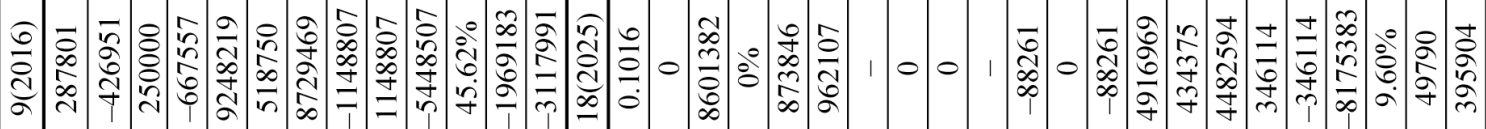

放


Analysis of which strategy is the best for TH and G to bargain will be discussed in the following sections.

\section{Analyses of TH's bargaining strategy}

$\mathrm{G}$ requests renegotiation and asks $\mathrm{TH}$ to propose a solution such as increasing investment, or allowing $G$ to directly purchase and take over assets according to conditions specified in the contract. Although the BOT project has no management value, according to Microeconomics, share-holders are certain to maximize the reward. TH owns the advantages of "agency dilemma" and "hold-up problem". TH will agree to renegotiate but refuses to increase its investment, and requests $\mathrm{G}$ to subsidize. Otherwise, TH will declare bankruptcy and request reconstruction in court. Under the "G zero investment" consensus of the general public, $G$ will strongly disagree with subsidies. Based on the position of $\mathrm{TH}$, the strategies $\mathrm{TH}$ can take in a game consisting of multiple sub-games to create negotiation superiority will be discussed in the following paragraphs.

\subsection{The competition strategy}

TH may declare bankruptcy and applies in court for reconstruction in order to be in advantageous position. Meanwhile, TH may halt the operation of HR to force G to renegotiate and agree to subsidies. The influence of financial incentives for declaring bankruptcy is analyzed as follows:

Objective of Reconstruction: (1) to reconstruct the capital structure of an enterprise to lower interest payments and debts, (2) to guarantee an increase of management investment, and (3) to discover and correct the basic causes for the financial problems faced by the enterprise.

Results of Reconstruction: During the period of reconstruction, proposed Objective (1) may be temporary. However, when TH bid on the BOT project, HR made mistakes on estimating a major HR-BOT variable volume of transportation. Additionally, reconstruction without expertise will make it impossible to increase future income, so that the above objectives (1), (2), and (3) will never be achieved. Thus, failure is expected, and the original investors will never recover their investment.

\subsection{The cooperation strategy}

The Public opinion supports $\mathrm{G}$ in taking strong measures by offering no subsidies to the developer. If $\mathrm{TH}$ adopts the cooperation strategy by giving up the management and allowing $G$ to purchase $H R$ assets, the maximum reward for TH shareholders is analyzed as follows: Assuming at time $t,[A t s=C t]>0$ with $(C t)$ being (see Fig. 4) the current residual rights and interests for $\mathrm{TH}$ shareholders (see Table 3 ) in the BOT project. If $\mathrm{TH}$ selects relinquishing the rights, to the shareholder, this selection is equivalent to buying their residual equity capital $(\mathrm{Ct})$ in the project within time $t$ at the cost of $C t$. Here, $C t$ is defined as:

$$
C t=(I-d t)-D t,\left\{\begin{array}{c}
S t \leq D t \quad \text { or } \quad S t>D t \\
S t=I-d t
\end{array}\right.
$$

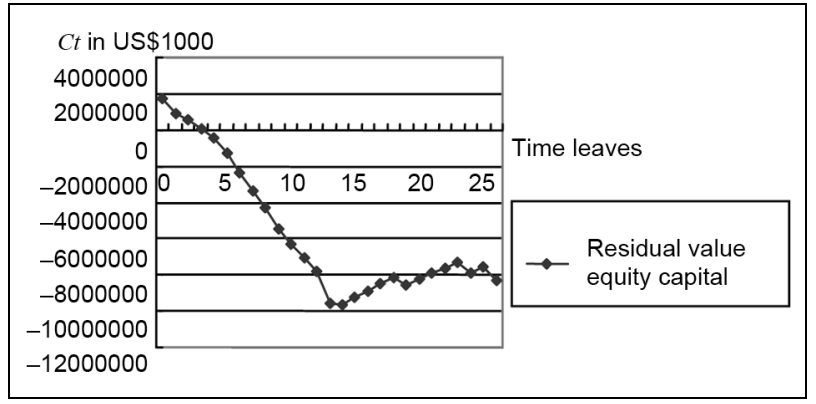

Fig. 4. Plot of $C t$ value/ Accounting Period (Data taken from Table 3)

In contrast, $\mathrm{G}$ offers $\mathrm{TH}$ the price of $C t$ for the rights. Fig. 4 plots the value of $C t$ ( $\mathrm{Y}$ axis) in $\$ 1000$ (shown in Row 22 of Table 3) versus time (X axis) (see Table 3) starting from 2007, when HR began operation as the "zero" period till 2037, when the contract will be terminated. At the end of the $4^{\text {th }}$ period (i.e. 2011), the residual value of all residual equity capital $(C t)$ is still positive $\left(+\$ 0.1\right.$ billion for the $3^{\text {rd }}$ period) meaning that the shareholders will be able to recover portions of their investment.

Different situations are considered below.

Situation 1: $C t \leq 0$. The investors have no current residual rights and interest. Based on the principle of Microeconomics, TH may select "refusing negotiation" by taking the "competition" strategy to declare bankruptcy and apply for reconstruction in court to play for time. During the lawsuit period, HR may stop operation, causing a severe loss for the general public. If $G$ wins the lawsuit, new conditions will be included in the bidding; the cost of preparing new bidding should be higher than the cost of renegotiation. Under these two situations, $G$ cannot bear the political fallout (Ho 2006), and G will not force TH to take the "competition" strategy. If G wins the lawsuit, new conditions will be included in the bidding; the cost of preparing new bidding should be higher than the cost of renegotiation. Under these two situations, $G$ cannot bear the political fallout (Ho 2006), and G will not force TH to take the "competition" strategy.

Situation 2: $\mathrm{Ct}>0$. Because the general public requires that $\mathrm{G}$ can no longer fall into the thinking that "TH must not fail" for the good of public affair, G will not offer subsidies for paying interest and compensating insufficient income (Yang 2007). The only alternative is to execute the "guaranteeing to purchase asses" clause to HR. Then TH will accept renegotiation by taking the "cooperation" strategy. However, the purchase of HR's assets by $\mathrm{G}$ is more beneficial to $\mathrm{G}$ as $A t$ is greater than and approaches $S t$ and $D t$. Therefore, G determines that delaying the purchase will have more benefit.

Hence, the results of negotiation for this stage should be as follows. After an asset appraisal, both $\mathrm{TH}$ and $\mathrm{G}$ know that the HR project does not have any management value. Nonetheless, $G$ is bearing the responsibility to keep HR in operation because it is a public welfare asset as stipulated by government policy. However, the general public will not agree with $\mathrm{G}$ offering more financial support to TH. Hence, G has no other choice but to 
take over HR assets. Backed by strong public opinion, $\mathrm{G}$ will not allow HR to make unlimited demands, and $\mathrm{TH}$ also understands the situation very well. Under the principle of maximizing the investment for investors, $\mathrm{TH}$ adopts the "cooperation" policy. However, the parties have different viewpoints. They disagree on the price for purchasing the assets and on the most appropriate time for HR to abandon the operation. This is the most serious crisis for salvaging the BOT project. According to the standpoint of TH, when $(A t-S t)>C t>0$ and $(A t-D t)>$ $\mathrm{Ct}>0$, the proceeds before 2011 are still positive (Table 3 ) or $C t>0$. Because the At offered by G for purchasing the asset cannot be estimated in advance, TH hopes that Ats $>0$, so that the expectation of $C t>0$ can be realized so that at least investors need not reinvest to compensate the loss. Accordingly, both parties gain, and the "cooperation" strategy can be completed in the game. Therefore, the best policy is $\mathrm{TH}$ completing the renegotiation and abandoning HR operation, and G guaranteeing the purchase of HR assets within 4 years after HR began operation in 2007.

\section{Conclusions}

Based on the "speculative behavior" and the "limited reasonable" cognition, TH not only won bidding at a higher bidding price but it also acquired the promise of purchase assets and loan guarantee from $\mathrm{G}$, even bargaining again and again afterword. However, what the operation of HR can bring in is much less than that $\mathrm{TH}$ had expected, which has caused TH to fall in a financial crisis. This research, via employing DCF method, computes that the NPV is $\$-21.6$ billion. It has fallen below the profound out-the-money, revealing that the HR project is not worth the value of further management. Based on Game Theory, TH must adopt the "cooperation" strategy and complete the renegotiation by 2011 , abandon the project, and allow $\mathrm{G}$ to guarantee the purchase of HR assets so that the financial crisis can be solved while the profit can be maximized. Meanwhile, in an incomplete contract, the bidder of opportunism can win the contract and through the superiority of the contractor forces the owner to concede. As such, the opportunists could gain tremendous profit. But when opportunists fall in the risk of over-optimistic market, "hold-up problem" and "agency dilemma" become the own disadvantages of renegotiation. As time goes on, the uncertainty may vary, and the competitive superiority and rights for the participants may change. The traditional methods of evaluating the operation strategy and planning for enterprises are all static, and the analysis is based primarily on the standpoint of representative policy makers. Therefore, such methods cannot be applied to the real market. Through verification, Game Theory allows policy makers to conduct multiple mutual interactions with opponents in an environment of conflict to select the actions that will maximize profit through competition. Although Game Theory models can stimulate creative thinking, it is abstract and it cannot provide the definite figure of reward. However, the HR case study will offer valuable information as the groundwork of judging the principle of "competition or cooperation". The findings from this case study will be a practicable method for the enterprise and the authorities to establish future BOT policies on renegotiation.

\section{References}

Aaken, A. 2009. International investment law between commitment and flexibility: A contract theory analysis, Indiana Journal of Global Legal Studies 16(2): 483-512.

Aneta, K.; Ewa, S. 2008. Public Private Partnership and Game Theory, Journal on Agricultural Economics 51(19): 93101.

Ashuri, B.; Kashani, H.; Molenaar, K. R.; Lee, S. 2010. A valuation model for choosing the optimal Minimum Revenue Guarantee (MRG) in a highway Project: A real-option approach, in Proc. of 2010 Construction Research Congress, Banff, 2010. Canada: Alberta, 1244-1253. http://dx.doi.org/10.1061/41109(373)125

Athias, L.; Nunez, A. 2009. The more the merrier? Number of bidders, information dispersion, renegotiation and winner's curse in Toll Road Concessions. MPRA Paper No. 10539, posted 17 September 2008. 39 p.

Aumann, R. 1959. Acceptable points in general cooperative nperson games, in A. W. Tucker and R. D. Luce (Eds.). Contributions to the Theory of Games, Volume IV. (AM40). Princeton University Press, 287-324.

Aumann, R. 1968. Values of Non-Atomic Games. Princeton University Press. 84 p.

Cheung, E.; Chan, A. P. C.; Kajewski, S. 2010. The public sector's perspective on procuring public works projects comparing the views of practitioners in Hong Kong and Australia, Journal of Civil Engineering and Management, 16(1): 19-32. http://dx.doi.org/10.3846/jcem.2010.02

Child, J.; Faulkner, D. 1998. Strategies of cooperation: Managing Alliances, Networks, and Joint Ventures. Oxford: Oxford University Press. 392 p.

Dahlstrom, R.; Nygaard, A. 1999a. Ownership decisions in plural contractual systems: Twelve networks from the quick service restaurant industry, European Journal of Marketing 33(1/2): 59-87. http://dx.doi.org/10.1108/03090569910249175

Dahlstrom, R.; Nygaard, A. 1999b. An empirical investigation of Ex Post Transaction Costs in franchised distribution channel, Journal of Marketing Research 36(2): 160-170. http://dx.doi.org/10.2307/3152090

Dewatripont, M. 1988. Commitment through renegotiationproof contracts with third Parties, Review of Economic Studies 55(3): 377-389. http://dx.doi.org/10.2307/2297390

Ellingsen, T.; Johannesson, M. 2004. Promises, threats and fairness, The Economic Journal 114(495): 397-420. http://dx.doi.org/10.1111/j.1468-0297.2004.00214.x

Fares, M. 2006. Renegotiation design and contract solutions to the hold-up problem, Journal of Economic Surveys 20(5): 731-756. http://dx.doi.org/10.1111/j.1467-6419.2006.00266.x

Flygbjerg, B; COWI. Procedures for Dealing with Optimism Bias in Transport Planning: Guidance Document. London: UK Department for Transport Press. 59 p.

Ginevičius, R.; Čirba, S. 2003. Competitive strategy of choosing parameters of building contracts, Journal of Civil Engineering and Management 9(1): 40-44. 
Grossman, S. J.; Hart, O. D. 1986. The costs and benefits of ownership: A theory of vertical and lateral integration, Journal of Political Economy 94(4): 691-719. http://dx.doi.org/10.1086/261404

Guasch, J. L.; Stphane, S. 2009. Corruption and concession renegotiations: Evidence from the water and transport sectors in Latin America, Journal of Utilities Policy 17(2): 185-190. http://dx.doi.org/10.1016/j.jup.2008.07.003

Hart, O.; Moore, J. 1990. Property rights and the nature of the firm, Journal of Political Economy 98(6): 1119-1158. http://dx.doi.org/10.1086/261729

Hill, C. W. L. 1990. Cooperation, opportunism, and the invisible hand: implications for transaction cost theory, Academy of Management Review 15(3): 500-513.

Ho, S. P. 2006. Model for financial renegotiation in PublicPrivate Partnership projects and its policy implications: Game Theoretic view, Journal of Construction Engineering and Management 132(7): 678-688.

http://dx.doi.org/10.1061/(ASCE)0733-9364(2006)132: $7(678)$

Ho, S. P. 2009. Government policy on PPP financial issues: Bid compensation and financial renegotiation, in A. Akintoye and M. Beck (Eds.). Policy, Finance and Management for Public-Private Partnerships. Blackwell Publishing Ltd., 267-300.

Hotchkiss, E. S.; Qian, J.; Song, W. 2004. Holdups, renegotiation and termination fees in mergers. Financial Institutions Center Working Paper Series, Philadelphia, USA. $50 \mathrm{p}$.

Hwang, P. 2006. Asset specificity and the fear of exploitation, Journal of Economics Behavior \& Organization 60(3): 423-438. http://dx.doi.org/10.1016/j.jebo.2004.04.007

Keršulienė, V.; Turskis, Z.; Zavadskas, E. K. 2010. Selection of rational method for customer-contractor dispute resolution with application of Game Theory, in Proc. of the 6th International Conference "Business and Management 2010", Selected papers, Vol. 2., 13-14 May, 2010, Vilnius, Lithuania, 1015-1020.

Klein, B. C.; Alchian, R. G.; Armen, A. 1978. Vertical integration, appropriable rents, and the competitive contracting process, Journal of Law and Economics 2(2): 297-326. http://dx.doi.org/10.1086/466922

Levy, S. M. 1996. Build, Operate, Transfer: paving the way for tomorrow's infrastructure. Willey. $411 \mathrm{p}$.

Makoto, H. 2004. Holdup with subsidized investment, Econometric Society 2004 Far Eastern Meetings, No 640.

Medda, F. 2007. A Game Theory approach for the allocation of risks in transport Public Private Partnerships, International Journal of Project Management 25(3): 213-218. http://dx.doi.org/10.1016/j.ijproman.2006.06.003

Myerson, R. B. 1991. Game Theory: Analysis of conflict. Harvard University Press. 600 p.

Nash, J. F. 1950. The bargaining problem, Econometrica 18(2): 155-162. http://dx.doi.org/10.2307/1907266

Nash, J. F. 1951. Non-cooperative games, Annals of Mathematics 54(2): 286-295. http://dx.doi.org/10.2307/1969529

Ostrom, E. 1990. Governing the commons: The evolution of institutions for collective action. Cambridge University Press. 298 p. http://dx.doi.org/10.1017/CBO9780511807763

Ostrom, E.; Schroeder, L.; Wynne, S. 1993. Institutional incentives and sustainable development: infrastructure policies in perspective. Oxford: Westview Press. 288 p.
Park, M.; Chu, Y.; Lee, H.-S.; Kim, W. 2009. Evaluation methods for construction projects, Journal of Civil Engineering and Management 15(4): 349-359.

http://dx.doi.org/10.3846/1392-3730.2009.15.349-359

Peldschus, F.; Zavadskas, E. K.; Turskis, Z.; Tamosaitiene, J. 2010. Sustainable assessment of construction site by applying Game Theory, Inzinerine Ekonomika - Engineering Economics (3): 223-237.

Rasmusen, E. B. 2001. Explaining incomplete contracts as the result of contract-reading costs, Journal of Advances in Economic Analysis Policy 1(1), Article 2. 30 p.

Rasmusen, E. B.; Lyon, T. P. 2004. Buyer-option contracts, renegotiation, and the hold-up problem, Journal of Law, Economics and Organization 20(1): 148-169. http://dx.doi.org/10.1093/jleo/ewh027

Rogerson, W. P 1992. Contractual solutions to the hold-up problem, Review of Economic Studies 59(4): 777-794. http://dx.doi.org/10.2307/2297997

Rozen, V.; Zhitomirski, G. 2006. A category theory approach to derived preference relations in some decision making problems, Mathematical Social Sciences 51(3): 257-273. http://dx.doi.org/10.1016/j.mathsocsci.2006.01.001

Sacks, R.; Harel, M. 2006. An economic Game Theory model of subcontractor resource allocation behavior, Construction Management and Economics 24(8): 869-881. http://dx.doi.org/10.1080/01446190600631856

Schelling, T. C. 1960. The strategy of conflict. Harvard University Press. 309 p.

Schnabel, C.; Wagner, J. 1992. Unions and innovative activity in Germany, Journal of Labor Research 13(4): 393-406. http://dx.doi.org/10.1007/BF02685529

Schweizer, U. 2000. An elementary approach to the hold-up problem with renegotiation. GEABA - Discussion Paper No. 00-01, Germany. 18 p.

Shen, L. Y.; Bao, H. J.; Wu, Y. Z.; Lu, W. S. 2007. Using Bargaining-Game theory for negotiating concession period for BOT-type contract, Journal Construction Engineering and Management ASCE 133(5): 385-392. http://dx.doi.org/10.1061/(ASCE)0733-9364(2007)133: $5(385)$

Tiong, R. L. K. 1995. Competitive advantage of equity in BOT tender, Journal of Construction Engineering and Management ASCE 121(3): 282-289. http://dx.doi.org/10.1061/(ASCE)0733-9364(1995)121: $3(282)$

Tiong, R. L. K.; Alum, J. 1997. Distinctive winning elements in BOT tender, Journal of Engineering Construction and Architectural Management 4(2): 83-94. http://dx.doi.org/10.1108/eb021041

Von Neumann, J.; Morgenstern, O. 1944. Theory of Games and Economic Behavior. Princeton University Press. 648 p.

Williamson, O. E. 1979. Transaction-cost economics: The governance of contractual relations, Journal of Law and Economics 22(2): 233-261. http://dx.doi.org/10.1086/466942

Yang, Y. 2007. Effect of diversification of operation cost on infrastructure BOT project investment decision and analysis of option gme, China Population, Resources and Environment $17(2)$ : 32-35.

Yaqub, M. Z. 2009. Antecedents, consequences and control of opportunistic behavior in strategic networks, Journal of Business and Economics Research 7(2): 15-32.

Yuan, J. F.; Skibniewski, M. J.; Li, Q.; Shan, J. 2010. The driving factors of China's Public-Private Partnership projects in metropolitian transportation systems: public sector's 
viewpoint, Journal of Civil Engineering and Management 16(1): 5-18. http://dx.doi.org/10.3846/jcem.2010.01

Zavadskas, E. K.; Turskis, Z. 2008. A new logarithmic normalization method in Games Theory, Informatica 19(2): 303314.

Zavadskas, E. K.; Ustinovichius, L.; Stasiulionis, A. 2004. Multicriteria valuation of commercial construction projects for investment purposes, Journal of Civil Engineering and Management 10(2): 151-166.

http://dx.doi.org/10.1080/13923730.2004.9636299
Zheng, S.; Tiong, R. L. K. 2010. First Public-PrivatePartnership application in Taiwan's wastewater treatment sector: case study of the Nanzih BOT Wastewater Treatment project, Journal of Construction Engineering and Management ASCE 136(8): 913-922.

http://dx.doi.org/10.1061/(ASCE)CO.1943-7862.0000196

Tien-Chien CHEN. PhD candidate in Dept of Civil Engineering, National Taipei University of Technology (NTUT) in Taiwan. He received the MS degree in the banking and finance program from the Tamkamg University in Taiwan (2005). His published researches are centered on three areas: 1) finance management, 2) Game theory application, and 3) real options analysis. His current research interests include financial management, construction economics, construction management, Game theory application, and BOT in construction.

Yu-Cheng LIN. Associate Professor of construction engineering and management at the Dept of Civil Engineering of the National Taipei University of Technology. He received the M.S. degree in the construction management program of civil engineering from the Polytechnic University, New York, USA and received PhD degree from the National Taiwan University in Taiwan (2004). His current research interests include construction knowledge management, building information modeling, web-based project management system, IT technology application, automation, E-Commerce related topics.

Lung-Chuang WANG. Professor of construction engineering and management at the Dept of Civil Engineering of the National Taipei University of Technology. He received the M.S. degree in the transportation management program from the National Chiao Tung University in Taiwan and received PhD degree from the National Central University in Taiwan (1998). His current research interests include construction management, project decision making, construction contract management, RFID-based technology application, government procurement law related topics. 